\title{
THE DYNAMICS OF PLANTS WATER USE, OPTIMIZATION OF IRRIGATION REGIMES CONSIDERING REGIONAL NATURAL AND CLIMATIC CONDITIONS
}

Kokovikhin S. V.

\section{INTRODUCTION}

An important element in the formation of irrigation regime of crops is the total water use or the amount of water that is needed for plants during the vegetation period to obtain a planned yield in specific natural conditions under the optimization of all technological processes. Water use consists of the water expenses on plants transpiration, evaporation from soil surface and formation of biological mass. In addition, it is necessary to take into account the water use of plants for individual stretches of the vegetation period. The soil moisture expenditures for individual stretches of the vegetation period according to meliorative terminology are called the total evaporation ${ }^{1,2,3}$.

Researches directed on the determination of differentiation zones of water-exchange of crops depending on different stages of growth and development, as well as abiotic and anthropogenic factors have a great theoretical and practical value. Firstly, the study of water use dynamics and the need for nutrients will allow to detect the means of influence on the water and nutrition soil regimes, to form the optimal model in the "Soil - atmosphere plant" system, secondly, these experimental data could be used for the formation of irrigation regimes (regulation of irrigation, adjustment of calculated layer of soil, choice of irrigation method), forecasting the actual level of yield, establishing statistical relations between the intensity of productive process and content and allocation of the productive moisture storages, etc. ${ }^{4}$.

In theoretical aspect, such an information is important for the determination of dynamics of the water regime in the system of functioning plant relations with the environment and the possibility of its regulation in

1 Изберик С. Назначение режимов орошения с использованием метеоданных. Реферативный журнал с.-х. мелиорации (Франция). 1978. № 4. С. 3.

2 Латифов Н. Л., Кобозев И. В., Парахин Н. В. Оптимизация режимов орошения сельскохозяйственных культур. Москва: МСХА, 1996. 94 с.

${ }^{3}$ Писаренко В. А., Тищенко П. В., Йокич Д. Р., Тищенко А. П. Рекомендации по применению водосберегающих режимов орошения на основе инструментального метода управления поливами в хозяйствах Крымской области. Симферополь : ИВЦ Крымоблагропрома, 1989. 25 с.

4 Михеева О. В. Совершенствование нормирования водосберегающих режимов орошения озимой пшеницы в условиях Саратовского Заволжья : автореф. дис... канд. техн. наук: 06.01.02. Саратов: СГАУ, 2005. $21 \mathrm{c.}$ 
various current hydro-thermal and agro-technological conditions. The applied nature of such materials is determined by the possibilities of their use for the substantiation of the calculated layer of soil, which is advisable to be humidified by vegetative watering at the minimization of gravitational expenditures of irrigation water and precipitation ${ }^{5}$. Besides, experimental data on the content in of nutrients and their dynamics in the soil depending on a complex of factors are required to be used for the optimization of fertilization system, improvement of economic efficiency and ecological status of agrocenoses.

\section{The dynamic of water use by alfalfa and winter wheat depending on the conditions of vegetation, stages of development and conditions of humidification}

The water use process in an open natural environment depends on many factors, the main of which is moisturizing of the surface itself and meteorological conditions: the intensity of solar radiation, air humidity and wind speed. The dependence of evaporation on the intensity of solar radiation is very complex. Rays of the sun are the source of those energy evaporation resources, without which it is almost impossible, since the evaporation of water requires near 600 calories of heat per $1 \mathrm{~g}$ of water ${ }^{6}$.

Observation on the total water use by alfalfa of different years of use shows that the total water use is mainly determined by the level of water supply of the plants (Table 1).

It should be noted that in the non-irrigated variant in all the years it is less than in the irrigated ones and in humid 2004 year it exceeded other more arid years. Due to minor irrigation norms in the years of the research, increasing total water use in the humid year is observed and in the conduct of watering using various ways.

It should be emphasized that alfalfa plants, regardless on weather conditions and application of irrigation, used moisture efficiently from the second meter of the soil. This is testified by the difference between the indicators of the total water use of two-meter and meter soil layers, which in the non-irrigated variant is equal on the average to $402 \mathrm{~m}^{3} / \mathrm{ha}$, at the surface method of irrigation - 346 and at the overhead sprinkler irrigation $289 \mathrm{~m}^{3} /$ ha, respectively. Total water consumption of alfalfa in the years of the research testifies to approximately the same share of soil moisture and precipitation in the non-irrigated variant.

\footnotetext{
${ }^{5}$ Лисогоров К. С., Писаренко В. А. Наукові основи використання зрошуваних земель у степовому регіоні на засадах інтегрального управління природними і технологічними процесами. Таврійський науковий вісник. 2007. Вип. 49. С 49-52.

${ }^{6}$ Константинов А. Р. Водный и тепловой режим орошаемых полей. Ленинград, 1979. $112 \mathrm{c}$.
} 
Table 1

Total water use of alfalfa of past years from different soil layers, $\mathrm{m}^{3} / \mathrm{ha}$

\begin{tabular}{|c|c|c|c|c|c|}
\hline \multirow{2}{*}{ Variant } & \multirow{2}{*}{$\begin{array}{l}\text { Soil } \\
\text { layer, } \\
\text { cm }\end{array}$} & \multicolumn{3}{|c|}{ Year of research } & \multirow{2}{*}{ Average } \\
\hline & & 2003 & 2004 & 2005 & \\
\hline \multirow{2}{*}{ Without irrigation } & $0-100$ & 2893 & 4622 & 2525 & 3347 \\
\hline & $0-200$ & 2954 & 5238 & 3055 & 3749 \\
\hline \multirow{2}{*}{$\begin{array}{l}\text { Surface watering } \\
\text { by strips }\end{array}$} & $0-100$ & 2711 & 6043 & 3340 & 4031 \\
\hline & $0-200$ & 3203 & 6218 & 3712 & 4378 \\
\hline \multirow{2}{*}{$\begin{array}{l}\text { Overhead sprinkler } \\
\text { irrigation }\end{array}$} & $0-100$ & 3125 & 6014 & 3397 & 4179 \\
\hline & $0-200$ & 3225 & 6388 & 3789 & 4467 \\
\hline \multirow{2}{*}{$\mathrm{LSD}_{05}, \mathrm{~m}^{3} / \mathrm{ha}$} & $0-100$ & 97.9 & 115.0 & 87.3 & - \\
\hline & $0-200$ & 119.4 & 121.8 & 91.4 & - \\
\hline
\end{tabular}

An important parameter for planning and operational management of irrigation regimes is the indicators of the daily use of moisture - yield evaporation or by the terminology accepted in the EU, USA, Canada, etc. evapotranspiration ${ }^{7,8}$ by the calendar dates of the vegetation period, as well as setting this indicator according to individual stages of plant development. This figure can be used to schedule the terms and norms of irrigation for crops. The average daily evaporation depends on many factors: the biological characteristics of crops, physical and mechanical properties of the soil, weather conditions, intensity of plant productive processes, agro-technological and meliorative measures, etc. ${ }^{9}$.

The results of the research determined that the large influence on the indices of evapotranspiration have a stage of development of individual crops, which can be linked to certain calendar dates, taking into account regional soil and climatic conditions. Additionally, the evaporation indices are significantly affected by the groundwater level. The researches performed found out that

${ }^{7}$ Frasier G. Runoff farming - Irrigation technology of the future. Future irrigation strategies. Visions of the Future. Proceedings of the 5-rd National Irrigation Symposium, 2003. Phoenix. P. 124-137.

${ }^{8}$ Harris T., Glover M., Wood T., Ulrich C. Transference of computerized irrigation cost budget generator. The Nevada experience. Computers Electronics in Agronomy. 1998. № 5. P. 161-165.

${ }^{9}$ Писаренко В. А., Коковіхін С. В., Мішукова Л. С., Писаренко П. В. Методичні вказівки по застосуванню розрахункового методу визначення строків поливу сільськогосподарських культур за показниками середньодобового випаровування. Херсон: Колос, 2005. 16 с. 
the average daily evaporation of alfalfa of past years depends on the factors listed above (Table 2).

Table 2

The average daily evaporation of alfalfa of past years (considered) depending on the groundwater level, $\mathrm{m}^{3} / \mathrm{ha}$

\begin{tabular}{|c|c|c|c|c|}
\hline \multirow{2}{*}{ Month } & \multirow{2}{*}{ Decade } & \multicolumn{3}{|c|}{ Groundwater level, M } \\
\hline & & More than 3.0 & $2.0-2.5$ & $1.0-1.5$ \\
\hline March & 3 & 15.0 & 9.8 & 6.0 \\
\hline \multirow{3}{*}{ April } & 1 & 29.0 & 18.8 & 11.6 \\
\hline & 2 & 22.9 & 14.9 & 9.2 \\
\hline & 3 & 26.6 & 17.3 & 10.6 \\
\hline \multirow{3}{*}{ May } & 1 & 40.9 & 24.5 & 12.3 \\
\hline & 2 & 40.5 & 24.3 & 12.2 \\
\hline & 3 & 41.8 & 25.1 & 12.5 \\
\hline \multirow{3}{*}{ June } & 1 & 48.2 & 28.9 & 12.0 \\
\hline & 2 & 41.3 & 24.8 & 10.3 \\
\hline & 3 & 55.7 & 30.6 & 13.9 \\
\hline \multirow{3}{*}{ July } & 1 & 49.3 & 27.1 & 12.3 \\
\hline & 2 & 51.9 & 28.5 & 13.0 \\
\hline & 3 & 46.7 & 25.7 & 11.7 \\
\hline \multirow{3}{*}{ August } & 1 & 48.9 & 26.9 & 12.2 \\
\hline & 2 & 43.1 & 23.7 & 10.8 \\
\hline & 3 & 46.9 & 25.8 & 11.7 \\
\hline \multirow{3}{*}{ September } & 1 & 35.6 & 19.6 & 10.8 \\
\hline & 2 & 32.1 & 17.7 & 9.6 \\
\hline & 3 & 22.9 & 12.6 & 6.7 \\
\hline \multicolumn{2}{|c|}{ Average $\left(x_{a v .} \pm s_{d}\right)$} & $38.9 \pm 2.6$ & $22.5 \pm 1.3$ & $11.0 \pm 0.5$ \\
\hline \multicolumn{2}{|c|}{ Coefficient of variation (V),\% } & 29.0 & 26.0 & 18.2 \\
\hline \multicolumn{2}{|c|}{ Confidence interval (min-max) } & $33.1 \div 44.7$ & $19.4 \div 25.5$ & $10.0 \div 12.1$ \\
\hline
\end{tabular}

The highest evaporation rates are fixed for deep (more than $3.0 \mathrm{~m}$ ) level of groundwater occurrence in the third decade of June $\left(55.7 \mathrm{~m}^{3} / \mathrm{ha}\right.$ per day), and also in the first and second decade of July (49.3-51.9 $\mathrm{m}^{3} /$ ha per day). As a result of the moisture requirements compensation due to the soil moisture, the minimum evapotranspiration is fixed under the medium (1.0-1.5 m) groundwater level, which in the same calendar dates averaged to 13.9, 12.3 and $13.0 \mathrm{~m}^{3} /$ ha per day, respectively.

Variable analysis proved the highest amplitude of alfalfa of past years evaporation fluctuations in the areas with deep occurrence of groundwater (confidence interval $33.1 \div 44.7 \mathrm{~m}^{3} /$ ha per day). The smallest variation factor ( $V=18.2 \%)$ was observed in the areas with close groundwater level, testifying about their stabilizing effect. 
Many studies have established that there are two large periods in the development of plants and water use in winter wheat: the first one - from the sprouts to the cessation of vegetation (with the termination of vegetation in winter); the second one is from the spring vegetation renewal and to full ripeness.

Scientific literature mainly provides information on the second period, but in some reports there are references and indicators of water use by plants from the sprouts to the winter period ${ }^{10,11}$.

However, most researchers do not pay attention to the expenditures of water in winter wheat during the cessation of vegetation in the winter period, which is an important part of the water balance of the field occupied by this crop.

The aim of our research was to establish the dynamics of total water use and value of the evaporation of winter wheat under the optimum irrigation regime from different layers of soil depending on the stages of plant development, calendar dates and depth of groundwater.

During the years of observations, the average amount of precipitation in the periods was: sprouts - cessation of vegetation $-660 \mathrm{~m}^{3} / \mathrm{ha}$, cessation of vegetation - spring regrowth $-1140 \mathrm{~m}^{3} / \mathrm{ha}$, spring regrowth - full ripeness of grain $-1897 \mathrm{~m}^{3} /$ ha, on the whole from sprouts to full ripeness of grain $3697 \mathrm{~m}^{3} /$ ha (Table 3). Analysis of the obtained experimental data on the use of moisture from different layers of the soil testifies that in the autumn and during the winter period of winter wheat development there is a gradual replenishment of water supplies in deep layers of the soil. The tendency to decrease in the rates of total water use from the soil layer $0-50 \mathrm{~cm}$ to the layer $0-200 \mathrm{~cm}$ is established. During the spring-summer vegetation, on the contrary, the total water use rates in these layers increased. The obtained data testify that in the spring and summer period the plants use water from the whole two-meter layer of the soil. In general, from sprouting to full ripeness of winter wheat, the active moisture exchange takes place in the range of the upper meter layer.

Comparison of the total water use of winter wheat field to the rainfall during the period from sprouting to full ripeness of grain allows determining water use deficit, which must be compensated through vegetative watering. The data provided in the table allows determining specific water use expenditures in the inter-stage periods. They show that during the winter period wheat crops lost about $700 \mathrm{~m}^{3} /$ ha of water, and the rainfall during the same time was $1140 \mathrm{~m}^{3} / \mathrm{ha}$. Consequently, owing to the winter period, the winter wheat field accumulates about $400-450 \mathrm{~m}^{3} /$ ha of soil moisture.

10 Гамаюнова В. В., Кузьмич А. О. Вплив післядії органо-мінеральної системи удобрення на площу листкової поверхні, продуктивність фотосинтезу та фотосинтетичний потенціал озимої пшениці. Таврійський науковий вісник. 2007. Вип. 55. С. 8-13.

${ }^{11}$ Мединец В. Могучий творец качества зерна пшеницы. Зерно. 2009. Июнь. С. 80-83. 

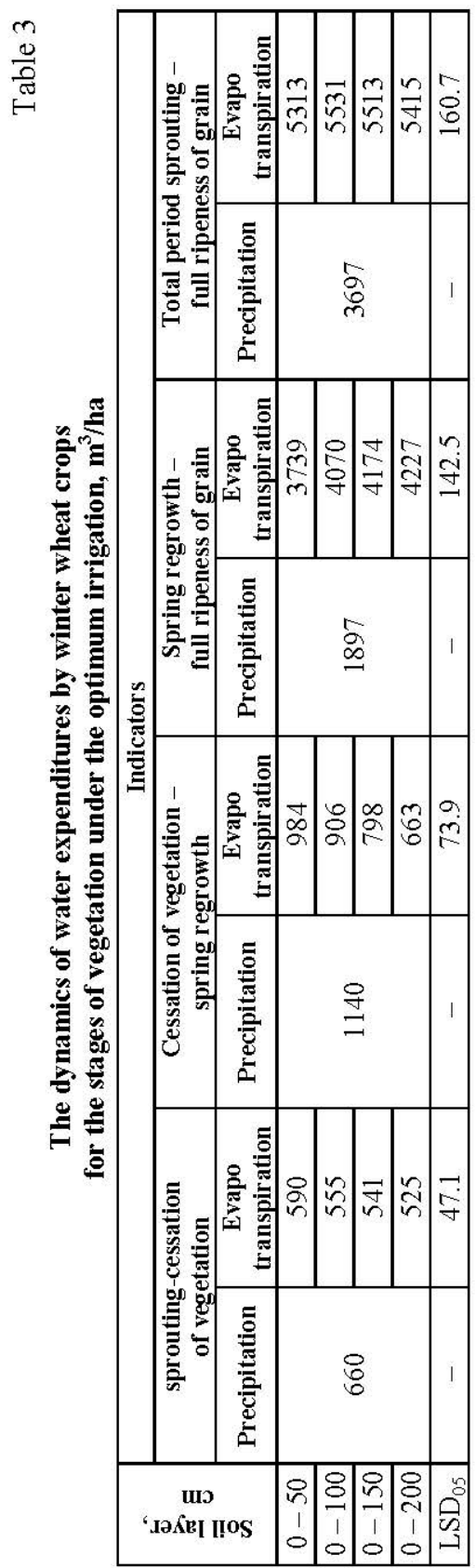

As for the spring-summer period of vegetation, there was the opposite trend marked - water expenditures for evapotranspiration, and therefore - to ensure the plants productivity processes, are 1.4-1.5 times higher than its income with of atmospheric precipitation. The shortage of available moisture, which was over the years of the research $1842-2330 \mathrm{~m}^{3} / \mathrm{ha}$, should be eliminated by the vegetative watering.

In the experiment on optimizing productive processes of winter wheat by choosing the most effective types of irrigation during the regrowth of plants moisture storage in twometer layer was (in \% to the mass of dry soil): in the variant without presowing irrigation -18.7 , with presowing irrigation $-19.4 \%$.

High initial moisture storage in two-meter soil layer, a significant amount of precipitation during the spring-summer vegetation, especially in humid years, positively affected the indices of total water use (Table 4).

On the average for two years, in the variants without irrigation and with one pre-sowing irrigation they were almost similar (3092 and $3175 \mathrm{~m}^{3} / \mathrm{ha}$ ). Carrying out vegetative watering resulted in the increase of the total water use, but it was not equivalent to irrigation norm. It should be emphasized that the rates of total water use were determined by the conditions of the spring-summer vegetation period, especially in the variants without irrigation.

In the variant with pre-sowing and vegetative watering water 
consumption by the years averaged to 3788 and $3540 \mathrm{~m}^{3} /$ ha, respectively. In the balance of water use in all the studied variants on the average for two years the largest share belongs to the rainfall of the vegetation period (53-63\%). Besides, in the variant with vegetative irrigation the percentage of soil water used decreases at the expense of them.

Table 4

Total water use and its balance depending on the conditions of water supply of winter wheat

\begin{tabular}{|l|c|c|c|c|c|c|c|}
\hline \multirow{2}{*}{ Variant } & \multirow{2}{*}{$\begin{array}{c}\text { Total } \\
\text { water use, } \\
\mathbf{m}^{\mathbf{3}} / \mathbf{h a}\end{array}$} & \multicolumn{3}{|c|}{ Balance of water use from the soil layer 0-200 cm } \\
\cline { 3 - 8 } & & \multicolumn{2}{|c|}{ Soil moisture } & \multicolumn{2}{|c|}{ Precipitation } & \multicolumn{2}{|c|}{ Irrigation } \\
\cline { 3 - 8 } & $\mathbf{m}^{\mathbf{3}} / \mathbf{h a}$ & $\mathbf{\%}$ & $\mathbf{\mathbf { m } ^ { 3 } / \mathbf { h a }}$ & $\mathbf{\%}$ & $\mathbf{m}^{\mathbf{3}} / \mathbf{h a}$ & $\mathbf{\%}$ \\
\hline $\begin{array}{l}\text { Control } \\
\text { (without } \\
\text { irrigation) }\end{array}$ & 3092 & 1132 & 37 & 1960 & 63 & - & - \\
\hline $\begin{array}{l}\text { Pre-Sowing } \\
\text { irrigation }\end{array}$ & 3176 & 1215 & 38 & 1960 & 62 & - & - \\
\hline $\begin{array}{l}\text { Pre-sowing } \\
\text { and vegetation } \\
\text { irrigation }\end{array}$ & 3664 & 904 & 25 & 1960 & 53 & 800 & 22 \\
\hline $\mathrm{LSD}_{05}, \mathrm{~m}^{3} / \mathrm{ha}$ & 164.2 & 51.8 & & & & & \\
\hline
\end{tabular}

Table 5

Average daily evaporation of winter wheat depending on the groundwater level, $\mathrm{m}^{3} / \mathrm{ha}$

\begin{tabular}{|c|c|c|c|c|}
\hline \multirow{2}{*}{ Month } & \multirow{2}{*}{ Decade } & \multicolumn{3}{|c|}{ Groundwater level, M } \\
\cline { 2 - 5 } & 2 & $\mathbf{O v e r} \mathbf{3 . 0}$ & $\mathbf{2 , 0 - 2 , 5}$ & $\mathbf{1 . 0 - 1 . 5}$ \\
\hline \multirow{2}{*}{ March } & 3 & 18.7 & 18.7 & 16.8 \\
\cline { 2 - 5 } & 1 & 22.9 & 19.3 & 17.4 \\
\hline \multirow{3}{*}{ April } & 2 & 28.9 & 20.6 & 18.3 \\
\cline { 2 - 5 } & 3 & 35.1 & 31.6 & 23.1 \\
\cline { 2 - 5 } & 1 & 37.7 & 33.9 & 25.3 \\
\hline \multirow{3}{*}{ May } & 2 & 40.0 & 36.0 & 30.2 \\
\cline { 2 - 5 } & 3 & 46.2 & 37.0 & 27.7 \\
\hline \multirow{3}{*}{ June } & 1 & 50.3 & 40.2 & 30.2 \\
\cline { 2 - 5 } & 2 & 35.7 & 28.6 & 21.4 \\
\cline { 2 - 5 } & 3 & 30.2 & 21.1 & 15.1 \\
\hline \multirow{2}{*}{ July } & 1 & 27.4 & 19.2 & 13.7 \\
\cline { 2 - 5 } & 2 & 28.0 & 19.8 & 14.0 \\
\hline \multicolumn{2}{|c|}{ Average $\left(x_{\text {av. }} \pm s_{d}\right)$} & $32.3 \pm 7.7$ & $27.1 \pm 6.0$ & $21.9 \pm 4.5$ \\
\hline \multicolumn{2}{|c|}{ Coefficient of variation $(V), \%$} & 85.6 & 80.0 & 73.2 \\
\hline \multicolumn{2}{|c|}{ Confidence interval $($ min-max $)$} & $15.1 \div 49.6$ & $13.4 \div 40.6$ & $11.9 \div 31.9$ \\
\hline
\end{tabular}


Winter wheat during the spring-summer period of vegetation used moisture differently by the stages of development depending on the conditions of water supply of the plants. On average by the years of the research in the variant with regular irrigation the average daily evaporation for inter-stage periods was: regrowth - tillering $-17.9 \mathrm{~m}^{3} / \mathrm{ha}$, tillering - earing - 50.8, earing - milk ripeness of grain $-44.1 \mathrm{~m}^{3} / \mathrm{ha}$ and milk - full ripeness of grain $12.6 \mathrm{~m}^{3} /$ ha. Despite the great amount of precipitation, especially in 2004, in the variant without irrigation the evaporation in the inter-stage periods "tillering - earing" and "earing - milk ripeness of grain were by 21.5 and $11.5 \mathrm{~m}^{3} /$ ha less than the indices in the watering plots.

Summarizing the results of the calculations, it is proved that the average daily evaporation of winter wheat depends on the calendar dates of the spring-summer period and on the groundwater level (Table 5).

The highest evapotranspiration $\left(50.3 \mathrm{~m}^{3} /\right.$ ha per day) was recorded in the first decade of June on the arrays with deep groundwater. The minimum evaporation values of $16.8-18.7 \mathrm{~m}^{3} /$ ha was at the beginning of regrowth in the second decade of March. On average for the spring and summer period daily water use decreased on the plots with the groundwater level of $2.0 \mathrm{~m}$ - by $16.1 \%$, and at $1.0 \mathrm{~m}$ - by $32.2 \%$, compared to the deep level of groundwater.

Statistical data processing determined very high amplitude of fluctuations in the studied indices - the coefficient of variation was 85.6, 80.0 and $73.2 \%$, respectively. This testifies about the increased variability in the daily evaporation of winter wheat and determines the need for careful control of the availability of easily accessible water to ensure the optimum passing of the productive processes.

\section{Study on the dynamics of water use of corn and soybean under their cultivation on the irrigated lands of southern steppe of Ukraine}

The studies of the scientists ${ }^{12,13,14,15,16}$ indicates the uneven spatial distribution of soil moisture by the surface of the field under the irrigation with large-scale sprinkler machinery and contains recommendations regarding

\footnotetext{
${ }^{12}$ Жовтоног О. I., Кириєнко О. І., Шостак I. К. Алгоритм планування зрошення 3 використанням геоінформаційних технологій для системи точного землеробства. Меліорація і водне господарство. 2004. Вип. 91. С. 33-41.

${ }^{13}$ Жуйков Г. С. Економічні засади ведення землеробства на зрошуваних землях. Херсон : Айлант, 2003. 288 c.

${ }^{14}$ Ромащенко М. І., Жовтоног О. І., Філіпенко Л. А., Деменкова Т. Ф. Методика планування оптимальних екологічно безпечних режимів зрошення. Київ: УкрНИИГиМ, 1997. C. 43.

${ }^{15}$ Коваленко П. І., Собко О. О., Писаренко В. А. Сучасний стан, основні проблеми водних меліорацій та шляхи їх вирішення. Київ: Аграрна наука, 2001. 274 с.

${ }^{16}$ Weatherhead E. K., Knox J. W. Drip irrigation revisited. Irrigation News. 1997. № 25. P. 77-79.
} 
the consideration of this inequality in irrigation scheduling to reduce the losses of yield and unproductive water expenditures.

The task of our study was to determine the spatial irregularity of soil moisture, average daily losses depending on natural and anthropogenic factors and to develop the optimized elements of corn cultivation technology.

On average by the years of the research in the non-irrigated variants the total water use was the minimum and averaged to $3293 \mathrm{~m}^{3} / \mathrm{ha}$. In the variants with irrigation, its parameters increased and averaged to (at the irrigation according to the scheme $60-80-60 \%$ FC) $4444 \mathrm{~m}^{3} / \mathrm{ha}$, and in the variants of irrigation regime of $80-80-80 \%$ FC $-4812 \mathrm{~m}^{3} /$ ha (Table 6).

Table 6

Total water use balance of the soil layer $0-200 \mathrm{~cm}, \mathrm{~m}^{3} / \mathrm{ha}$

\begin{tabular}{|l|c|c|c|c|}
\hline \multirow{2}{*}{$\begin{array}{c}\text { Irrigation } \\
\text { regimes, \% FC }\end{array}$} & $\begin{array}{c}\text { Indices } \\
\text { moisture used } \\
\text { from the soil }\end{array}$ & $\begin{array}{c}\text { Precipit } \\
\text { ation }\end{array}$ & $\begin{array}{c}\text { Irrigation } \\
\text { norm }\end{array}$ & $\begin{array}{c}\text { Total water } \\
\text { use }\end{array}$ \\
\hline Without irrigation & 1003 & 2290 & - & 3293 \\
\hline $60-80-60 \mathrm{FC}$ & 687 & 2290 & 1467 & 4444 \\
\hline $80-80-80 \mathrm{FC}$ & 589 & 2290 & 1933 & 4812 \\
\hline $\mathrm{LSD}_{05}, \mathrm{~m}^{3} / \mathrm{ha}$ & 34.0 & - & - & 187.3 \\
\hline
\end{tabular}

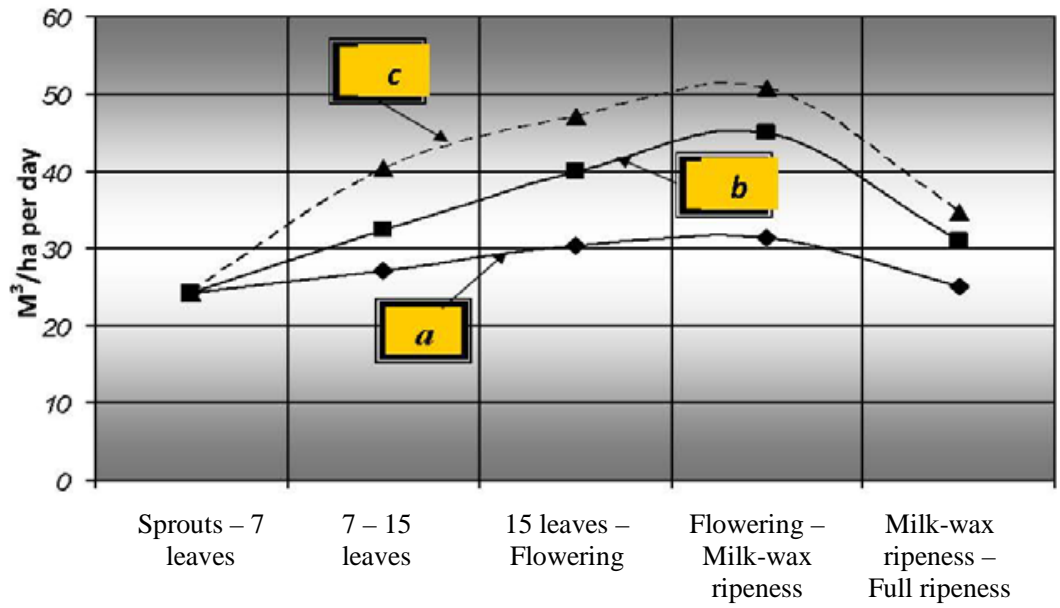

Fig. 1 Average daily evaporation by the inter-stage periods of self-pollinated lines of corn in the variants without irrigation $(a)$, with irrigation 60-80-60\% FC (b) and 80-80-80\% FC (c) 
The proportion of soil moisture in the balance of the total water use of unirrigated variants of the experiment is $30.6 \%$, including the use from the second meter of the soil $-11.9 \%$. In the irrigated variants, the share of soil moisture is much lower (12.2-18.4\%) than in the rain-fed conditions, and the main water supply of the plants was formed by the rainfall and vegetation watering.

In our researches we determined the average daily evaporation by corn in different inter-stage periods. It was determined that at the beginning of the vegetation period (sprouts -7 leaves) daily expenditures of soil moisture were the minimum and averaged to $24.2 \mathrm{~m}^{3} /$ ha (Fig. 1).

The maximum daily evaporation was in the period of "Flowering Milk-wax ripeness" and averaged in the variants without irrigation to $31.5 \mathrm{~m}^{3} / \mathrm{ha}$, at the irrigation with $60-80-60 \%$ FC to $45.2 \mathrm{~m}^{3} / \mathrm{ha}$, at $80-80-80 \%$ $\mathrm{FC}-50.8 \mathrm{~m}^{3} / \mathrm{ha}$. After the stage of milk-wax ripeness of grain there was a gradual decrease in this index.

Thus, the studies have shown that the greatest water use is in the period of "Flowering - Milk-wax ripeness of grain" that must be taken into account in the formation of the regimes of irrigation of corn hybridization plots. The average daily evaporation in the irrigated conditions increased depending on the irrigation regimes and stages of the plant development in 1.1-1.5 times compared to the non-irrigated plots.

It should be noted that there was no significant effect of growth regulators and plants density on the value of the indices of water use both in general and on the daily levels.

The results of the observations for initial soil moisture testify that in the spring at the beginning of the growing season there is a significant discrepancy in the magnitude of this index on the different fields of the irrigated crop rotation. Despite the leveling effect of precipitation of the autumn-winter period, the difference in productive moisture content on some fields of the crop rotation was from 73.2 to $323.3 \mathrm{~m}^{3} / \mathrm{ha}$, or $6.5-28.6 \%$. We also recorded the variation in soil moisture by individual sections of irrigated array (Fig. 2).

The experimental data on the dynamics of water use the plants of selfpollinated lines of corn allowed setting the intensity of water expenditures from different layers of the soil by stages of growth and development of the plants, and also depending on hydrothermal peculiarities of the years. At the beginning of corn plant development (first 15-30 days of vegetation) water is most intensively used from the soil layer $0-30 \mathrm{~cm}$, where the root system of the young plants is placed.

While on-surface organs growth and penetration of the root system water is mainly used from deeper layers of the soil. In the second month highly intensive use of water begins from the soil layer $0-50 \mathrm{~cm}$, but in the dry years, this zone extends to the depth of $70 \mathrm{~cm}$. In the second half of the 
vegetation period, non-irrigated corn uptakes water from deeper layers of the soil. It should be mentioned that the basic water-exchange zone does not go beyond $0-70 \mathrm{~cm}$, but weather conditions of the growing season and especially precipitation, correct the areas of intensity of water consumption at different stages of the plant development.

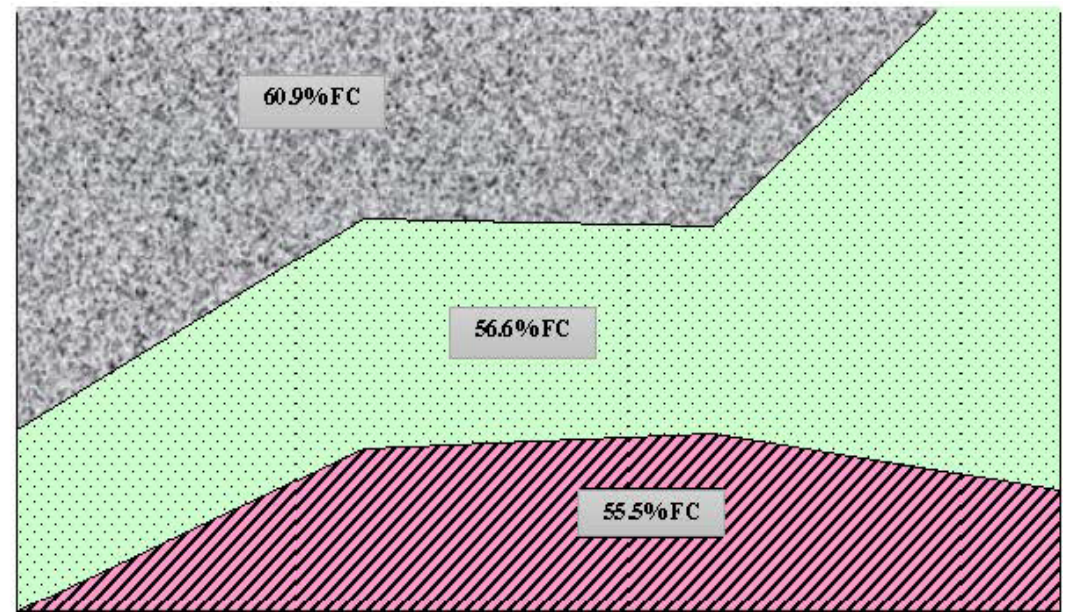

Fig. 2 Difference in soil moisture by individual plots of the field No. 3 of the irrigated areas of corn hybridization after harvesting in the soil layer 0-50 cm

It is noted that in the dry years there is a gradual increase of the soil layer from which the plants use water intensively. This regularity is also observed in the moderate by the deficit of evaporation years, but the zone of intensive water-exchange slightly changes, especially in the second half of vegetation. On the contrary, in humid years the intensive water requirements almost does not change and significant amount of precipitation promotes substantial replenishment of the contents of total and productive moisture.

Ranking the years of the study has shown that at the initial stages of growth and development of corn plants on the plots of hybridization average daily evaporation is insignificant (25.7-29.7 $\left.\mathrm{m}^{3} / \mathrm{ha}\right)$ and slightly depends on meteorological factors (the difference is only 4.1-13.4\%). Further analysis of daily water expenditures by individual stages of the vegetation period revealed significant difference in this index, starting with the stage of 7-15 leaves depending on the level of both natural and artificial humidification.

The highest average daily evaporation during the vegetation period of self-pollinated lines is observed in the dry years and it was $40.2 \mathrm{~m}^{3} / \mathrm{ha}$, and the minimum $\left(31.1 \mathrm{~m}^{3} / \mathrm{ha}\right)$ - in humid ones. Regarding individual stages of development the maximum average daily evaporation $\left(63.0 \mathrm{~m}^{3} / \mathrm{ha}\right)$ was 
observed in the period "flowering - milk ripeness of grain" in the dry years, and the minimum $\left(14.5 \mathrm{~m}^{3} / \mathrm{ha}\right)$ it was in the humid years in the period from milk to full ripeness of grain.

Rapid increase in the indices of evapotranspiration was observed on the irrigated plots, especially in the dry and moderately humid years. Further (after the stage of 15 leaves) the expenditures of water increased and reached the maximum level in the period from flowering to milk ripeness of grain. Average daily evaporation of middle-late hybrids of corn is significantly dependent on the stages of the plants development (vegetation calendar dates) and the depth of groundwater (Table 7).

The maximum evapotranspiration of $59.6 \mathrm{~m}^{3} /$ ha per day was recorded in the second decade of July and coincides with the maximum intensity of plants productivity processes. The least daily water use $\left(11.8-14.8 \mathrm{~m}^{3} / \mathrm{ha}\right)$ was recorded at the beginning of the vegetation - a period of "sprouts 3-5 leaves".

The variation analysis approved the maximum variability ( $V$ of 92.5 , 84.9 and $75.8 \%$, respectively) of the daily evaporation during the growing season, which predetermined the highest amplitude of confidence interval of this index - from $11.8 \div 32.8$ (groundwater level of $1.0-1.5 \mathrm{~m}$ ) to $15.3 \div$ $56.7 \mathrm{~m}^{3} /$ ha per day (at the deep groundwater level).

Table 7

Average daily evaporation of hybrids depending on the groundwater level, $\mathrm{m}^{3} / \mathrm{ha}$

\begin{tabular}{|c|c|c|c|c|}
\hline \multirow{2}{*}{ Month } & \multirow{2}{*}{ Decade } & \multicolumn{3}{|c|}{ Groundwater level, m } \\
\cline { 2 - 5 } & & More than 3.0 & $\mathbf{2 . 0 - 2 . 5}$ & $\mathbf{1 . 0 - 1 . 5}$ \\
\hline \multirow{3}{*}{ May } & 2 & 14.8 & 14.1 & 11.8 \\
\cline { 2 - 5 } & 3 & 17.6 & 16.7 & 14.1 \\
\hline \multirow{3}{*}{ June } & 1 & 25.4 & 24.1 & 20.3 \\
\cline { 2 - 5 } & 2 & 32.8 & 31.2 & 25.2 \\
\hline \multirow{3}{*}{ July } & 3 & 37.9 & 36.0 & 30.3 \\
\cline { 2 - 5 } & 1 & 48.4 & 36.3 & 26.6 \\
\cline { 2 - 5 } & 2 & 59.6 & 44.7 & 32.8 \\
\hline \multirow{3}{*}{ August } & 3 & 55.2 & 41.4 & 30.4 \\
\cline { 2 - 5 } & 2 & 49.2 & 36.9 & 27.1 \\
\cline { 2 - 5 } & 3 & 38.8 & 29.1 & 17.5 \\
\hline \multirow{2}{*}{ September } & 1 & 29.2 & 24.2 & 17.7 \\
\cline { 2 - 5 } & 2 & 26.7 & 20.0 & 16.0 \\
\hline \multicolumn{2}{|c|}{ Average $\left(x_{\text {av. }} \pm s_{d}\right)$} & $36.0 \pm 9.2$ & $29.0 \pm 6.8$ & $22.3 \pm 4.7$ \\
\hline \multicolumn{2}{|c|}{ Coefficient of variation $(V), \%$} & 92.5 & 84.9 & 75.8 \\
\hline \multicolumn{2}{|c|}{ Confidence interval $($ min-max $)$} & $15.3 \div 56.7$ & $13.6 \div 44.3$ & $11.8 \div 32.8$ \\
\hline
\end{tabular}


Taking into account the difference in the growing season of corn hybrids of different ripening groups, we conducted ranking of total and daily evaporation rates depending on the FAO groups at the deep groundwater level (Table 8).

Through the accounting it was determined that the maximum expenditures regardless the group of ripening were observed in the second decade of July, but in the middle-late hybrids evapotranspiration was by $10.4 \%$ higher, and on average by the vegetation this difference decreased to $3.7 \%$.

Statistical analysis found out almost identical coefficients of variations and confidence intervals, which reflect very high variability in water use of corn plants of different groups of ripening. Statistical analysis of perennial studies of the Institute of irrigated Agriculture of NAAS allowed constructing integral curves of yield evaporation from the soil layer 0-100 cm of different by a group of ripening soybean varieties (Fig. 5).

All the studied varieties demonstrated a rapid increase in daily evaporation, starting from 15 to 40 days of the growing season. It should be mentioned that in ultra-early varieties there was a decrease in this index, starting from the 53 day of the vegetation, and in the early and middleripening ones it was recorded only on the 58 and 64 day, respectively. According to the polynomial regression equations, indices of daily evaporation could be predicted in different by the ripening speed soybean varieties and they could be used to carry out operative control of the irrigation regime.

Systematization of total evaporation indices from the soil layer 0-100 $\mathrm{cm}$ of different by the ripening speed soybean varieties showed that this parameter increases from the ultra-early ripening varieties to the late ripening ones.

The study of the intensity of water use under the optimum irrigation regime revealed a clear tendency to the increase in the value of total and daily evaporation from dry years to humid ones. Data analysis discovered that water use of crops depends on the conditions of natural humidification and ranges from 3578-4421 $\mathrm{m}^{3} / \mathrm{ha}$ in dry and moderate by the evaporation deficiency years, up to $4725-5860 \mathrm{~m}^{3} / \mathrm{ha}$ - in moderately humid and humid years.

In dry and moderate years, there is a rapid increase in daily evaporation, starting from the first decade of July. Further, in dry years daily water expenditures are reduced from the first decade of August, and in the moderate years, on the contrary, at this period, the maximum value of this index $\left(68.0 \mathrm{~m}^{3} / \mathrm{ha}\right)$ is recorded. In the humid years there is a slight dynamics to an increase and decrease of daily evaporation by the decades of the growing season. The maximal average daily evaporation (more than $55 \mathrm{~m}^{3} / \mathrm{ha}$ ) is observed from the first decade of July. It dramatically increases in the moderate and dry years and remains high until the third decade of July - the first decade of August. In addition, the tendency to the increase in daily evaporation from humid years $\left(29.8 \mathrm{~m}^{3} / \mathrm{ha}\right)$ to dry ones (35.4-37.7 $\left.\mathrm{m}^{3} / \mathrm{ha}\right)$ was recorded. 
The total $(E)$ and average daily $\bar{E}$ evaporation of different by the ripening period corn hybrids, $\mathrm{m}^{3} / \mathrm{ha}$

\begin{tabular}{|c|c|c|c|c|c|}
\hline \multirow[t]{2}{*}{ Month } & \multirow[t]{2}{*}{ Decade } & \multicolumn{2}{|c|}{$\begin{array}{c}\text { FAO 250-350 } \\
\text { (middle-early and } \\
\text { middle-ripening hybrids) }\end{array}$} & \multicolumn{2}{|c|}{$\begin{array}{l}\text { FAO 400-600 } \\
\text { (Middle-late) }\end{array}$} \\
\hline & & $E$ & $\bar{E}$ & $E$ & $\bar{E}$ \\
\hline \multirow{2}{*}{ May } & 2 & 130 & 13.0 & 110 & 11.0 \\
\hline & 3 & 174 & 15.8 & 190 & 17.2 \\
\hline \multirow{3}{*}{ June } & 1 & 224 & 22.4 & 255 & 25.5 \\
\hline & 2 & 345 & 34.5 & 362 & 36.2 \\
\hline & 3 & 462 & 46.2 & 368 & 36.8 \\
\hline \multirow{3}{*}{ July } & 1 & 469 & 46.9 & 481 & 48.1 \\
\hline & 2 & 501 & 50.1 & 559 & 55.9 \\
\hline & 3 & 518 & 47.1 & 536 & 48.9 \\
\hline \multirow{3}{*}{ August } & 1 & 426 & 42.6 & 462 & 46.2 \\
\hline & 2 & 357 & 35.7 & 414 & 41.4 \\
\hline & 3 & 285 & 28.5 & 354 & 35.4 \\
\hline \multirow{2}{*}{ September } & 1 & 231 & 23.1 & 300 & 30.0 \\
\hline & 2 & - & - & 242 & 24.4 \\
\hline \multicolumn{2}{|c|}{ Average $\left(x_{a v .} \pm s_{d}\right)$} & $343.5 \pm 109.5$ & $33.8 \pm 9.0$ & $356.4 \pm 109.0$ & $35.1 \pm 9.0$ \\
\hline \multicolumn{2}{|c|}{$\begin{array}{l}\text { Coefficient of variation } \\
(V), \%\end{array}$} & 110.5 & 91.8 & 110.3 & 92.3 \\
\hline \multicolumn{2}{|c|}{$\begin{array}{l}\text { Confidence interval } \\
\text { (min-max })\end{array}$} & $97.6 \div 589.4$ & $13.7 \div 53.9$ & $111.7 \div 601.1$ & $15.0 \div 55.3$ \\
\hline
\end{tabular}

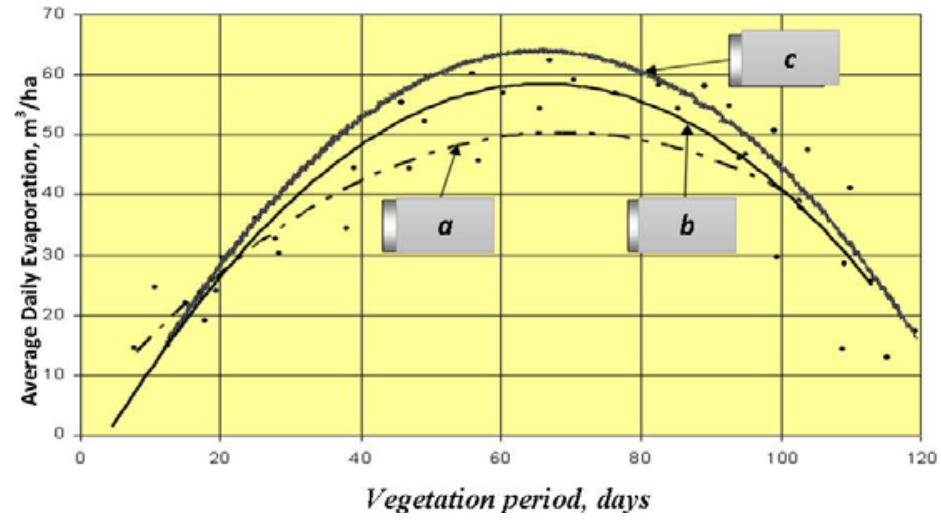

Fig. 3. Indices of daily evaporation of different

by the ripening speed soybean varieties:

a - ultra-early ripening $\left(\mathrm{y}=-0,0091 \mathrm{x}^{2}+1,456 \mathrm{x}-10.232 ; \mathrm{r}=0.863 ; \mathrm{R}^{2}=0.745\right)$;

b - early-ripening $\left(y=-0,0156 x^{2}+2,265 x-20.458 ; r=994 ; R^{2}=0.916\right)$

c - middle-ripening $\left(y=-0,0169 x^{2}+2,224 x-9.227 ; r=994 ; R^{2}=0.963\right)$ 


\section{CONCLUSIONS}

1. Alfalfa plants, regardless on weather conditions and application of irrigation, effectively used moisture from the second meter of the soil. The balance of total water use of alfalfa testifies about the same share of soil moisture and precipitation in the non-irrigated variant and significant reduction in their specific share on the irrigated areas. The highest indices of alfalfa evaporation are recorded at the deep groundwater level in the third decade of June. Variable analysis proved the highest amplitude of fluctuations in the daily evaporation of alfalfa of past years in the areas with deep groundwater level.

2. While determining the total water use of winter wheat we should consider the expenses of water for the period from cessation of vegetation in the winter to its regrowth in the spring, as well as the income of atmospheric precipitation during this period. The highest evapotranspiration $\left(50.3 \mathrm{~m}^{3} / \mathrm{ha}\right.$ per day) was recorded in the first decade of June in the areas with deep groundwater level. On the average by the spring and summer period daily expenditures decreased in the areas with the groundwater level of $2.0-2.5 \mathrm{~m}$ by $16.1 \%$, and at those ones with the groundwater level of $1.0-1.5 \mathrm{~m}-$ by $32.2 \%$, compared with the deep level of their allocation.

3. The studies approved a significant difference in soil moisture content depending on the fore-crops, irrigation regimes etc. The differentiation of water content in the soil is also observed in individual areas of the field, and this is due to the differences in the relief of the location, unequal distribution of irrigation water by the irrigation machines, etc., which allows to recommend conducting planning of irrigation schedules for the local areas of individual fields within the crop rotation. Mathematical analysis found the indices of variations and confidence intervals almost identical, which reflect very high variability water use of corn plants.

4. The average daily evaporation varies by the periods of the development of soybean plants, at the beginning and at end of the vegetation it is the minimum - 19.3-33.6 $\mathrm{m}^{3} / \mathrm{ha}$, and the maximum values of the index are reached at the period from flowering to the beginning of ripeness of beans (44.1-63.4 $\mathrm{m}^{3} / \mathrm{ha}$ ). In dry and moderate years, a rapid increase in daily evaporation, starting from the first decade of July, is recorded.

\section{SUMMARY}

The article presents the results of the studies on the dynamics of water use by plants, optimization of irrigation regimes considering regional natural and climatic conditions. It was established that alfalfa, regardless on weather conditions and application of irrigation, effectively used moisture from the second meter of the soil. The balance of total water use of alfalfa testifies about the equal share of soil moisture and precipitation on the non-irrigated 
variant and the significant decrease of their specific share on the irrigated plots. The highest indices of alfalfa evaporation are recorded at the deep groundwater level in the third decade of June. Variable analysis proved the highest amplitude of fluctuations of the daily evaporation of alfalfa of past years in the areas with the deep groundwater level. While determining the total water use of winter wheat we should consider the expenses of water for the period from cessation of vegetation in the winter to its regrowth in the spring, as well as the income of atmospheric precipitation during this period. It was proved that there is a differentiation in water content in the soil by individual sub-zones within the field, and this is explained by the variations in the relief of the location, uneven distribution of irrigation water by the sprinkler irrigation machines, etc., which allows to recommend scheduling irrigation regimes by the local areas of individual fields within the crop rotation. Mathematical analysis revealed almost identical indices of variations and confidence intervals, which reflect very high variability of water use of corn plants. The average daily evaporation is changed by the periods of soybean plants development, at the beginning and at the end of the vegetation it reaches the minimum, and the maximum values are recorded in the period from flowering to early ripeness of beans. In dry and moderate years, there is a rapid increase in daily evaporation, starting from the first decade of July.

\section{REFERENCES}

1. Изберик С. Назначение режимов орошения с использованием метеоданных. Реферативньй журнал с.-х. мелиорации (Франщия). 1978. № 4. C. 3.

2. Латифов Н. Л., Кобозев И. В., Парахин Н. В. Оптимизация режимов орошения сельскохозяйственных культур. Москва: МСХА, 1996. 94 c.

3. Писаренко В. А., Тищенко П. В., Йокич Д. Р., Тищенко А. П. Рекомендации по применению водосберегающих режимов орошения на основе инструментального метода управления поливами в хозяйствах Крымской области. Симферополь : ИВЦ Крымоблагропрома, 1989. 25 с.

4. Михеева О. В. Совершенствование нормирования водосберегающих режимов орошения озимой пшеницы в условиях Саратовского Заволжья : автореф. дис... канд. техн. наук: 06.01.02. Саратов: СГАУ, 2005. $21 \mathrm{c}$.

5. Лисогоров К. С., Писаренко В. А. Наукові основи використання зрошуваних земель у степовому регіоні на засадах інтегрального управління природними і технологічними процесами. Таврійський науковий вісник. 2007. Вип. 49. С 49-52.

6. Константинов А. Р. Водный и тепловой режим орошаемых полей. Ленинград, 1979. 112 с. 
7. Frasier G. Runoff farming - Irrigation technology of the future. Future irrigation strategies. Visions of the Future. Proceedings of the 5-rd National Irrigation Symposium, 2003. Phoenix. P. 124-137.

8. Harris T., Glover M., Wood T., Ulrich C. Transference of computerized irrigation cost budget generator. The Nevada experience. Computers Electronics in Agronomy. 1998. № 5. P. 161-165.

9. Писаренко В. А., Коковіхін С. В., Мішукова Л. С., Писаренко П. В. Методичні вказівки по застосуванню розрахункового методу визначення строків поливу сільськогосподарських культур за показниками середньодобового випаровування. Херсон: Колос, 2005. 16 с.

10. Гамаюнова В. В., Кузьмич А. О. Вплив післядії органомінеральної системи удобрення на площу листкової поверхні, продуктивність фотосинтезу та фотосинтетичний потенціал озимої пшениці. Таврійський науковий вісник. 2007. Вип. 55. С. 8-13.

11. Мединец В. Могучий творец качества зерна пшеницы. Зерно. 2009. Июнь. С. 80-83.

12. Жовтоног О. І., Кириєнко О. І., Шостак I. К. Алгоритм планування зрошення 3 використанням геоінформаційних технологій для системи точного землеробства. Меліорайія $i$ водне господарство. 2004. Вип. 91. С. 33-41.

13. Жуйков Г. Є. Економічні засади ведення землеробства на зрошуваних землях. Херсон : Айлант, 2003. 288 с.

14. Ромащенко М. І., Жовтоног О. І., Філіпенко Л. А., Деменкова Т. Ф. Методика планування оптимальних екологічно безпечних режимів зрошення. Київ: УкрНИИГиМ, 1997. С. 43.

15. Коваленко П. І., Собко О. О., Писаренко В. А. Сучасний стан, основні проблеми водних меліорацій та шляхи їх вирішення. Київ: Аграрна наука, 2001. 274 с.

16. Weatherhead E. K., Knox J. W. Drip irrigation revisited. Irrigation News. 1997. № 25. P. 77-79.

Information about the author: Kokovikhin S. V., Doctor of Agricultural Sciences, Professor, Institute of Irrigated Agriculture of National Academy of Agrarian Sciences of Ukraine Kherson, Naddnipryanske, 73483, Ukraine 